\title{
二球の非弾性衝突 \\ Non elastic impact of two balls
}

\author{
正 竹園 茂男(豊技大) 正 感本 広文(豊技大) \\ 永井 基之(豊技大院)
}

Shigeo TAKEZONO, Toyohashi University of Technology, 1-1, Tempaku-cho, Toyohashi, Aichi Hirofumi MINAMOTO, Toyohashi University of Technology, 1-1, Tempaku-cho, Toyohashi, Aichi Motoyuki NAGAI, Toyohashi University of Technology, 1-1, Tempaku-cho, Toyohashi, Aichi

Key Words:Non-elastic impact,impact of two balls,F.E.M, Coefficient of Restitution

\section{1. 粕 官}

二球の衝突問題は工学上基本的でかつ重要な問題の1 つであるにもかかわらず、動的接触という複雑な現象を 伴うためその解析例は少ない。古くは、Hertzの弾性接 触理論を用いて衝突速度と衝突時間の関係などが考察さ れている(1)(2)(3)。また、これらの理論を弾塑性域にまで 拡張した理論解析も提案されているが(4)(5)、球の衝突現 象が十分に明らかにされたとは言い難い。

そこで本研究では二球の衝突実験を行い、反発係数、 衝突後の接触円直径及び球の変形量を調べた。また有限 要素法によって二球の弾塑性衝突解析を行い、反発係数 に対する塑性変形の影響を調べた。そして反発係数を速 度の関数で表し、実験結果と比较した。

\section{2.二球の重突实験}

\section{1 实験装望及ひ方法}

二球の衝突実験をFig.1に示す実験装直で行った。一 方の球を空気圧により加速させ(衝突球と呼ぶ)、静止し ている球(被衝突球と呼ぶ)に衝突させた。弁の開閉は手 動で行い、ハイスピード・ビデオシステムを用い二球の 変位を時間間隔1/18000[s]で撮影した。ここで、Fig.2に ハイスピード・ビデオシステムにより撮影した衝突前、 衝突中、衝突後のビデオイメージの一例を示す。この ビデオイメージから(1)式を用い反発係数を求めた。ま た試験後、接触円直径及び球の变形量を測定した。

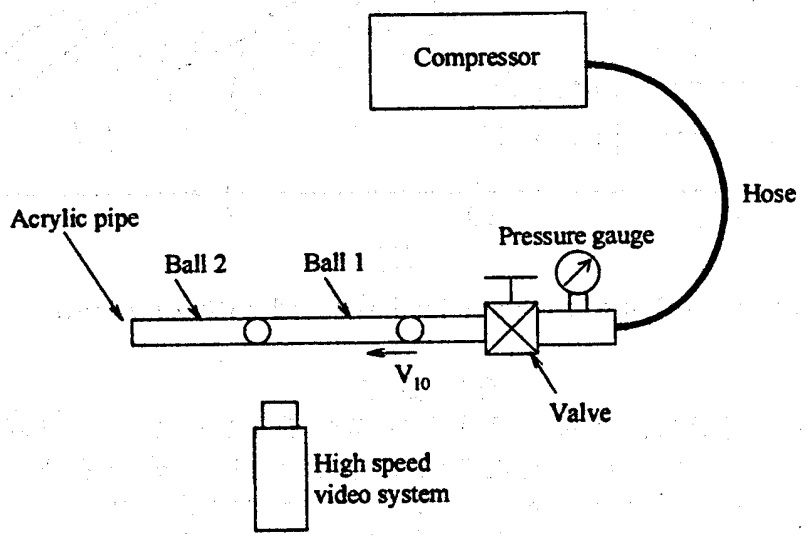

Fig.1 Experimental apparatus

$$
\begin{gathered}
e=\frac{V_{2}-V_{1}}{V_{10}-V_{20}} \cdots \cdot(1) \\
\text { e:反発係数 }
\end{gathered}
$$

$\mathrm{V}_{10}$ : 衝突前の衝突球の速度 $[\mathrm{m} / \mathrm{s}]$ $\mathrm{V}_{20}$ : 衝突前の被衝突球の速度 $[\mathrm{m} / \mathrm{s}]$

$\mathrm{V}_{1}$ : 衝突後の衝突球の速度 $[\mathrm{m} / \mathrm{s}]$

$\mathrm{V}_{2}$ :衝突後の被衝突球の速度 $[\mathrm{m} / \mathrm{s}]$

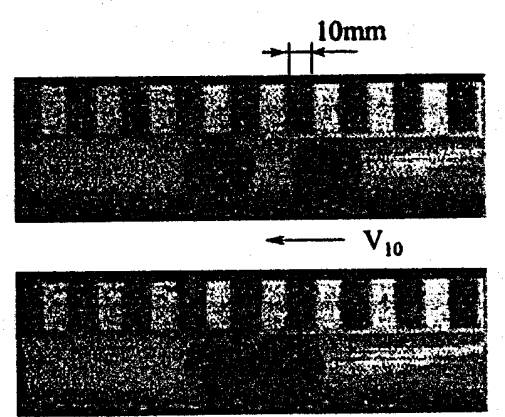

Before impact

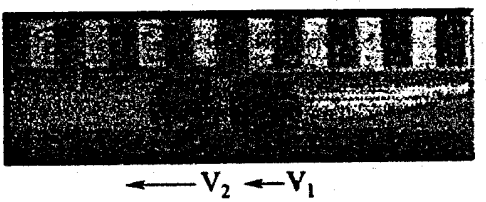

After impact

Fig.2 An example of high speed video image

\section{2 实罌条件}

試験片には焼きなまし処理を行った直径1インチ、材 質SUJ2(高炭素クロム軸受鎆)の鎆球を用いた。また、 Fig.3にSUJ2の真応力-真ひずみ線図を示す。

球を加速させるための圧力(ゲージ压)は0.3、0.6、 $0.8[\mathrm{MPa}]$ の 3 種類 $(\mathrm{Vi}=15 \sim 25[\mathrm{~m} / \mathrm{s}])$ で、各々 3 回の試倹 を行った。

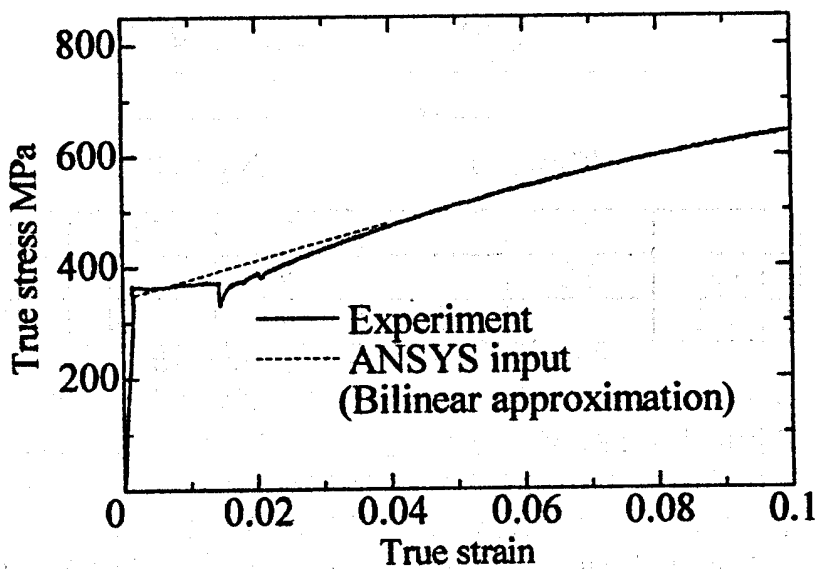

Fig.3 True stress-True strain

\section{3. 有限要率法による二球の弾塑性画乫解析}

汎用有限要素解析ソフト(ANSYS)を用い、同一形状・ 同一材質の二球が互いに衝突速度 $\mathrm{V}_{\mathrm{i}}$ で衝突する問題を解

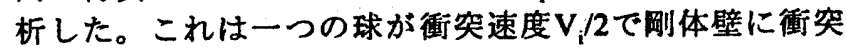


する問題と等価である。球の軸対称性を考慮して要素に は大ひずみ大変形を考虑した2次元構造ソリッド要素 (plane42)を、球と威体壁の接触には2次元点一㴊体面接 触要素(contac26)を使用した。Fig.4(a),(b)に解析に用いた 球の要素分割および接触点近傍の㹡大図を示す。球が局 部変形を生じるため、接触点近傍では要素分割を細かく とりそれ以外の部分は大きな要素分割とした。なお球材

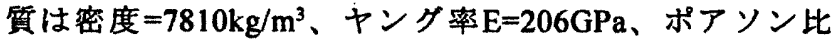
$\nu=0.3$ とし、Fig.3の破線に示す応力ーひずみ関係を用い た。

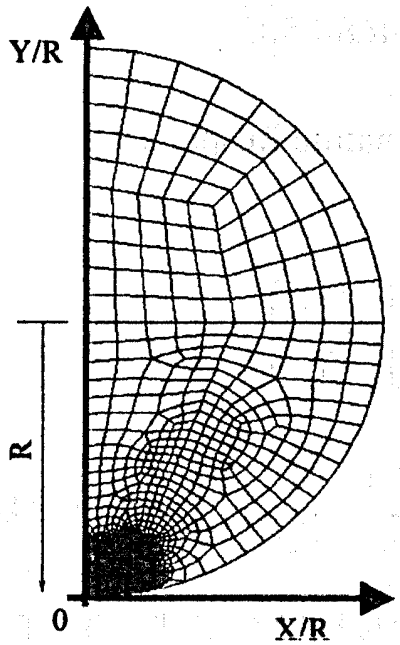

1218 nodes 1167 elements

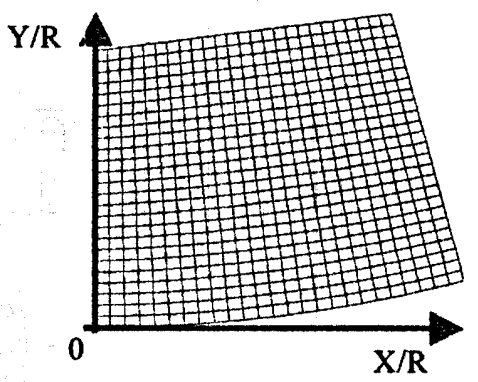

(b)Detail of fine meshed area

Fig.4 Finite element mesh

\section{4. 实験結果とシミューレーション結果の比较}

反発係数の害験結果とシミュレーション結果を Fig.5に示す。なおVi=0.8 2.5m/sの反発係数は文献(6) から引用した。また、Fig.6に球の衝突過程を示す。 $a_{\max }$ は最大変形時の接触円直径、aは衝突後の接触円直径、 衝突後の触接円直径及び球の変形量の実験結果とシミ ュレーション結果をFig.7に示す。

Fig.5とFig.7より次のことが分かった。

・反発係数は実験結果よりもシミュレーション結果の方 がやや低くなっている

- 衝突後の接触円直径及び球半径の堿少量は共に実験結 果よりもシミュレーション結果の方が高くなっている

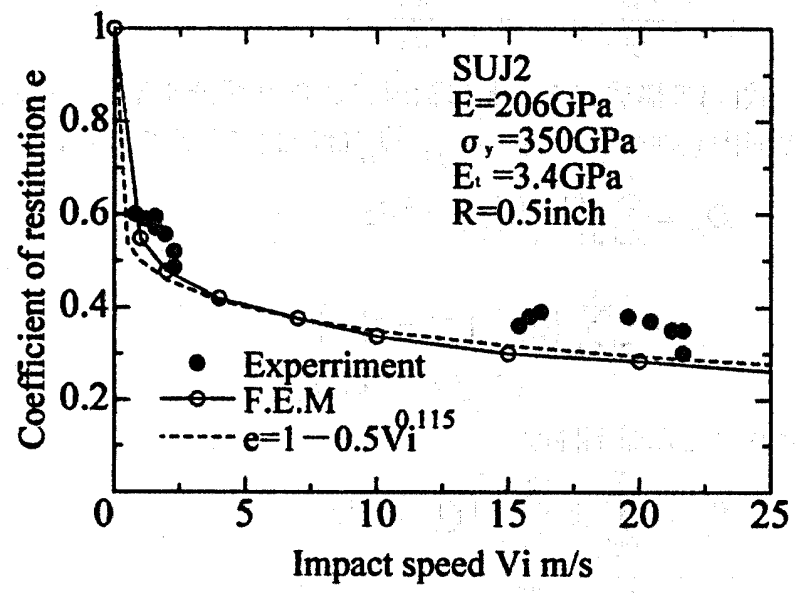

Fig. 5 Coefficient of restitution e

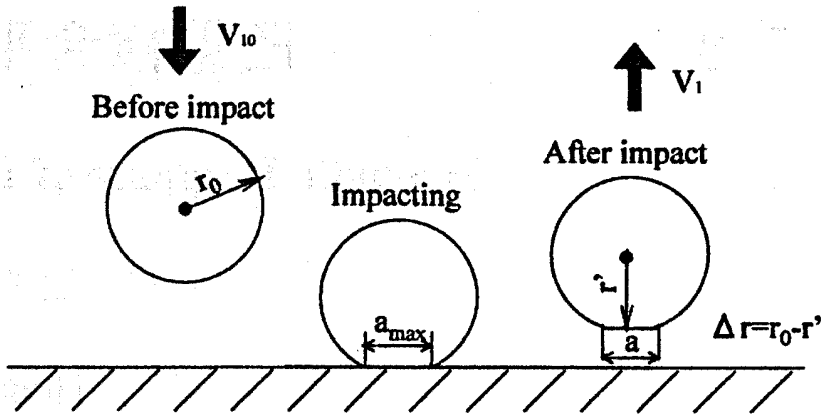

Rigid wall

Fig.6 Process of impact

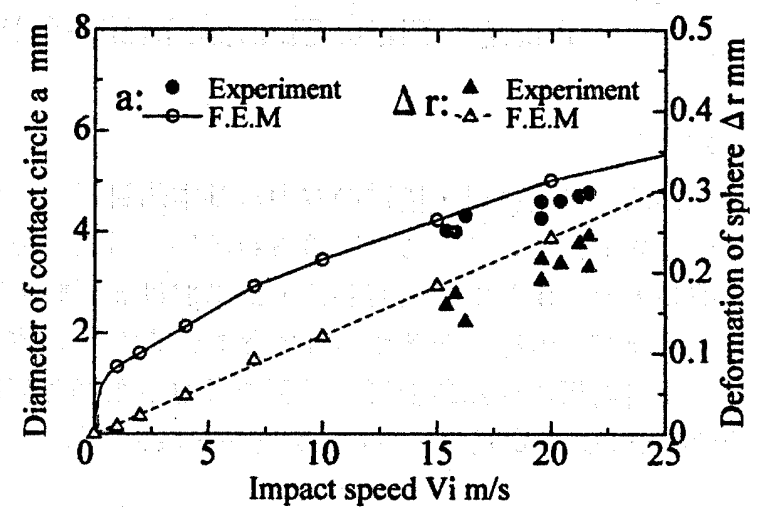

Fig.7 Diameter of contact circle and Deformation of sphere

\section{5. 考察}

反発係数が実験結果よりもシミュレーション結果の方 が低くなり、衝突後の接触円直径及び球の変形量におい ては実験結果がシミュレーション結果よりも低くなるの は、ひずみ速度が高くなると粘性の影響が現れ、球が硬 化し塑性変形が小さくなるからである。

\section{6. 結贯}

本研究では二球の衝突実験を行い反発保数を速度の関 数で表し、有限要菜解析の結果と比較した。これより、 球の衝突解析には新たに粘性の影響を考虑する必要があ ると考えられる。

従って、今後は高ひずみ速度域での材料試験の結果を 用いて弾粘塑性解析を行う予定である。

$$
\text { 文献 }
$$

(1)S.P.Timoshenko and J.N.Goodier, Theory of Elasticity (THIRD EDITION),McGRAW - HILL KOGAKUSHA, 413-436.

(2)P.Villaggio, The Rebound of an Elastic Sphere Against a Rigid Wall,Trans,.ASME,J.,Appl.Mech.Vol63(1996), 259-263.

(3)Goldsmith,W.,Impact,(1960),Edward Arnold.

(4)Thornton,C.,Coeffieient of restitution for collinear collisions of elastic-perfectly plastic spheres, Trans, ASME,J.,Appl.Mech., Vol64(1997).383-366.

(5)K.L.Johonson,Contact Mechanics, Cambridge University Press.

(6)S.Takezono and H.Minamoto M.Mitsuyama M.Nagai, AN ELASTO-PLASTIC IMPACT OF TWOBALLS, Proceedeings of the 4th International Symposium on Impact Engineering Vol. II ,2001,639-644. 